\title{
Design Methodology of New Furniture Joints
}

\section{Metodologija dizajniranja novih spojeva za namještaj}

\author{
Original scientific paper • Izvorni znanstveni rad \\ Received-prispjelo: 30. 3. 2016. \\ Accepted-prihvaćeno: 6. 9. 2016. \\ UDK: $630 * 824.523$ \\ doi:10.5552/drind.2016.1622
}

\begin{abstract}
Techniques for self-assembly and disassembly of furniture are predominant mainly in the group of cabinet furniture. The lack of new constructions of furniture joints affects the market development of skeletal furniture intended for self-assembly. These connections should have the following characteristics: be easy to assemble and disassemble, have a minimum number of components, meet aesthetic requirements and be externally invisible. The aim of the study was to develop a methodology for formulating the assumptions for designing a new connection of skeletal furniture. At the outset, the distinguished joint features were presented. Then, assessment criteria were formulated for each feature, with adeqate numerical values. On this basis, specific joints and fittings for skeletal furniture were collected and divided into 84 groups. The prepared numerical values were used as the data for statistical analysis. In the first step of the analysis, relationships were characterized between the studied features using the Spearman rank correlation. On the basis of statistical analysis, the correctness of the obtained classification was confirmed. Based on the analysis of the characteristics of the cluster and Spermans correlation coefficient values, there was no reason to highlight any qualities as a component of project assumptions. Cluster analysis pointed to differences between groups, as well as goups having similar features. Against this background, a clear design assumption was built.
\end{abstract}

Keywords: furniture, joints, design, brief, cluster analysis

SAŽETAK • U skupini korpusnog namještaja uglavnom prevladavaju tehnička rješenja za samostalnu montažu $i$ demontažu namještaja. Nedostatak novih konstrukcijskih spojeva za namještaj utječe na razvoj tržišta korpusnog namještaja namijenjenoga samostalnoj montaži. Konstrukcijski spojevi korpusnog namještaja trebali bi se moći lako sastaviti i rastaviti, imati minimalan broj komponenata, zadovoljiti estetske uvjete i biti izvana nevidljivi. Cilj istraživanja bio je razviti metodologiju za formuliranje pretpostavki za projektiranje novoga konstrukcijskog spoja za korpusni namještaj. Na početku rada prikazana su istaknuta obilježja pojedinih spojeva. Potom su za svako obilježje formulirani kriteriji vrednovanja, kojima su dodijeljene brojčane vrijednosti. Prikupljeni su i u 84 skupine grupirani različiti spojevi i elementi za spajanje korpusnog namještaja. Tako pripremljene numeričke vrijednosti uvrštene su kao podaci u statističke analize. U prvom koraku analize primjenom Spearmanove korelacije ranga određeni su odnosi između istraživanih obilježja. Na temelju statističke analize potvrđena je ispravnost dobivene klasifikacije. Na temelju klasterske analize obilježja i Spermanova koeficijenta korelacije pokazalo se da nema razloga za naglašavanje bilo kojeg obilježja kao sastavnog dijela projektne pretpostavke. Klasterska analiza

\footnotetext{
${ }^{1}$ Authors are PhD student and professor at Poznan University of Life Sciences, Faculty of Wood Technology, Department of Furniture Design, Poznan, Poland. ${ }^{2}$ Author is professor at Poznan University of Life Sciences, Faculty of Agriculture and Bioengineering, Department of Mathematical and Statistical Methods, Poznan, Poland. ${ }^{3}$ Author is doctor at Poznan University of Medical Sciences, Department of Computer Science and Statistics, Poznan, Poland.

${ }^{1}$ Autori su doktorand i profesor Sveučilišta bioloških znanosti u Poznanju, Fakultet drvne tehnologije, Zavod za dizajn namještaja, Poznanj, Poljska. ${ }^{2}$ Autor je profesor Sveučilišta bioloških znanosti u Poznanju, Fakultet agronomije i bioinženjeringa, Zavod za matematičke i statističke metode, Poznanj, Poljska. ${ }^{3}$ Autor je doktor Sveučilišta medicinskih znanosti u Poznanju, Zavod za računalne znanosti i statistiku, Poznanj, Poljska.
} 
označuje različitosti među skupinama, ali i povezuje skupine koje imaju zajednička obiljě̌ja. Na temelju dobivenih rezultata formulirane su jasne pretpostavke za dizajn novih spojeva korpusnog namještaja.

Ključne riječi: namještaj, spojevi, dizajn, uputa, klasterska analiza

\section{INTRODUCTION}

\section{UVOD}

Joints fulfil important strength, technological and operational-aesthetic functions in furniture constructions. This is confirmed by numerous publications analysing the influence of different factors on skeleton furniture joint strength depending on the kind of: joint, composite material and glue, as well as its impact on stress distribution (Smardzewski and Papuga, 2004; Kociszewski, 2005; Tankut and Tankut, 2006). It was demonstrated that joint stiffness increased together with the application of a greater number of connecting links (Liu and Eckelman, 1998), and that stiffness of a construction can be enhanced by increasing thickness of the applied materials (Tankut, 2009). In addition, studies conducted by (Vassiliou and Barboutis, 2009) showed that joint strength changed slightly depending on the manufacturer of the same type of connectors. On the basis of the available literature (Eckelman, 1997; Smardzewski and Prekrat, 2002; Eckelman, 2003), it can be said that, in general, joints are the weakest parts of a given piece of furniture and that furniture durability depends, first and foremost, on their quality.

In the case of skeleton furniture, it can be said that a considerable number of furniture joints consists of a tenon and mortise (Dzięgielewski and Zenkteler, 1975; Akcay et al., 2005; Eckelman and Haviarova, 2008; Smardzewski, 2008, 2015). Such joints are characterised by very good technical properties as well as by the fact that they are invisible outside. Their mechanical properties are commonly evaluated using destructive methods (Atar and Özçifçi, 2008; Altinok et al., 2009; Maleki et al., 2012; Yerlikaya and Aktas, 2012). Continuous efforts are being made to find new joint constructions, which would: ensure their easy assembly and disassembly, consist of a minimum number of components, be characterised by simple construction, look nice and be invisible outside (Smardzewski, 2015a). These requirements are difficult to realise both in terms of technical and technological solutions.

Innovative products usually evolve in the course of the product development process. The complexity of such processes can involve: designing, styling, marketing as well as planning of the product and appropriate production processes (Vajna and Kittel, 2009). The selection of designing assumptions is one of many stages of this proces (Ginalski et al., 1994).

It is worth emphasising that precise determination of designing assumptions is the precondition, to a considerable extent, of the success or failure of the entire project. There is no universal method for choosing such assumptions and each designer employs his/her own individual approach. The most popular methods include: brainstorming technique and its numerous variants (Buzan and Buzan, 2004) and heuristic methods (Daly et al., 2012).
Bearing in mind the above, the authors decided to propose a method of assumption selection to be used in designing new skeleton furniture joints. The method presents a procedure involving a systematic and universal selection of design assumptions for every kind of product. Using this procedure, it is possible to group appropriate, interesting features of a given product, which will be important from the point of view of properties of the new furniture joint.

The undertaken investigations aimed at elaborating methodology of developing assumptions to be used when designing a new skeleton furniture joint. The cognitive objective of the study was to select a group of joints characterised by similar features, whose value provided recommendations for the development of new constructions for skeleton furniture joints.

\section{MATERIALS AND METHODS}

\section{MATERIJAL I METODE}

Bearing in mind the solutions discussed in the above Introduction and presented in the study objective, the authors decided to distinguish the following features characterising joints: visibility, separability, assembly force, method of connection, tools, aesthetics, recycling and Coefficient of Assembly (CoA). Next, evaluation criteria were formulated for each feature; they were assigned the following numerical values: $1,0.5$ and 0 , where 1 - refers to an unfavourable criterion, 0.5 - intermediate and $0-$ a favourable criterion.

The value of CoA was calculated from the following formula:

$$
\operatorname{CoA}=\left(N_{F}+N_{E}\right) \cdot N_{O}
$$

$N_{F}$ in the above formula refers to the number of connecting links, $N_{E}$ - to the number of elements in the joint and $N_{O}$ designates the number of operations necessary to assemble the joint. These values were applied to evaluate the ease of assembly of a given joint (Table 1).

In the case of the dowel type of joint, the number of links $N_{F}$ is 1 , the number of elements $N_{E}$ in the joint amounts to 2 and the number of operations necessary to assemble the joint $N_{O}$ is 6 (because in order to assemble the joint, the following consecutive operations must be performed: drilling of two seats -2 , glue application to each seat -2 , placing of the link in one seat -1 , pressing down the assembly elements until the adhesive solidifies - 1). The CoA for this type of joint equals 18 (Table 2). In the case of the VB $25 \mathrm{~T}$ joint, the number of links $N_{F}$ is 3 , the number of elements $N_{E}$ in the joint amounts to 2 and the number of operations necessary to assemble the joint $N_{O}$ is 8 . The $C o A$ for this type of joint equals 40 .

Taking into account the established features and the adopted criteria of their evaluation, Table 3 collates 84 characteristic joints and connecting links of skele- 
Table 1 Features, criteria and numerical values of skeleton furniture joints evaluation

Tablica 1. Obilježja, kriteriji i numeričke vrijednosti za vrednovanje konstrukcijskih spojeva namještaja

\begin{tabular}{|c|c|c|}
\hline $\begin{array}{l}\text { Feature } \\
\text { Obilježje }\end{array}$ & $\begin{array}{l}\text { Evaluation criterion } \\
\text { Kriterij vrednovanja }\end{array}$ & $\begin{array}{l}\text { Rank } \\
\text { Rang }\end{array}$ \\
\hline \multirow[t]{3}{*}{$\begin{array}{l}\text { Visibility } \\
\text { Vidljivost }\end{array}$} & $\begin{array}{l}\text { completely visible } \\
\text { potpuno vidljiv }\end{array}$ & 1 \\
\hline & $\begin{array}{l}\text { partially visible } \\
\text { djelomično vidljiv }\end{array}$ & 0.5 \\
\hline & Invisible / nevidljiv & 0 \\
\hline \multirow[t]{2}{*}{$\begin{array}{l}\text { Separability } \\
\text { Odvojivost }\end{array}$} & $\begin{array}{l}\text { non-separable } \\
\text { neodvojiv }\end{array}$ & 1 \\
\hline & separable / odvojiv & 0 \\
\hline \multirow{2}{*}{$\begin{array}{l}\text { Assembly force } \\
\text { Sila sastavljanja }\end{array}$} & external / vanjska & 1 \\
\hline & internal / unutarnja & 0 \\
\hline \multirow[t]{2}{*}{$\begin{array}{l}\text { Method of connection } \\
\text { Način sastavljanja }\end{array}$} & $\begin{array}{l}\text { using glue / upotrebom } \\
\text { ljepila }\end{array}$ & 1 \\
\hline & $\begin{array}{l}\text { based on friction force } \\
\text { na temelju sile trenja }\end{array}$ & 0 \\
\hline \multirow[t]{2}{*}{ Tools / Alati } & $\begin{array}{l}\text { using tools / uz primjenu } \\
\text { alata }\end{array}$ & 1 \\
\hline & $\begin{array}{l}\text { without using tools } \\
\text { bez primjene alata }\end{array}$ & 0 \\
\hline \multirow[t]{2}{*}{$\begin{array}{l}\text { Aesthetics } \\
\text { Estetika }\end{array}$} & $\begin{array}{l}\text { unfavourable } \\
\text { neprikladna }\end{array}$ & 1 \\
\hline & $\begin{array}{l}\text { favourable } \\
\text { prikladna }\end{array}$ & 0 \\
\hline \multirow{3}{*}{$\begin{array}{l}\text { Recycling } \\
\text { Recikliranje }\end{array}$} & metal / metal & 1 \\
\hline & plastic / plastika & 0.5 \\
\hline & wood / drvo & 0 \\
\hline \multirow[t]{3}{*}{$\operatorname{CoA}$} & $C o A>36$ & 1 \\
\hline & $19<o A \leq 36$ & 0.5 \\
\hline & $19<o A \leq 36$ & 0 \\
\hline
\end{tabular}

ton furniture. When selecting the joints, the following properties were taken into consideration: functionality, technical-aesthetic and technological quality as well as strength. The selected joints were divided into groups to allow better differentiation of ways of mounting of connecting links: using glue, catch, screw, bolt, wedge, spring and magnet. Table 3 also contains symbols of joints (codes), which were used in the course of analyses carried out later.

Two groups of joints are described below together with their brief characterisations. In the first group, joints, which employ glue, are presented (AAA, AAB, AAC, AAD, AAE, AAF, AAG, AAH, and AAI). They

Table 2 Example of $C o A$ values

Tablica 2. Primjeri vrijednosti koeficijenta spoja $(C o A)$

\begin{tabular}{|l|l|l|l|l|l|}
\hline $\begin{array}{l}\text { Illustration } \\
\text { Ilustracija }\end{array}$ & $\begin{array}{l}\text { Name of connector } \\
\text { Naziv konektora }\end{array}$ & $\mathbf{N}_{\mathbf{F}}$ & $\mathbf{N}_{\mathbf{E}}$ & $\mathbf{N}_{\mathbf{O}}$ & CoA \\
\hline & VB 25 T & 3 & 2 & 8 & 40 \\
\hline & RASTEX & 2 & 2 & 7 & 28 \\
\hline & DOWEL & 1 & 2 & 6 & 18 \\
\hline
\end{tabular}

are non-separable and externally invisible. They are frequently employed in combination with other connectors and external force acting on the furniture body is necessary.

The second group comprises catch joints (BAA, BAB, BAC, BAD, BAE, BAF, BAG, BAH, BAI, BAJ, BAK, BAL, BAM, BAN, BAO, BAP, BAQ, BAR, BAS, BAT, BAU). These joints include solutions in which immobilisation of elements and their pressure is achieved by turning an appropriate coupler resulting in a mounting load. Usually, these are separable joints, partially visible externally. They guarantee stable assembly also when repeated assembly and disassembly is necessary.

In order to illustrate differences between evaluation of individual features for selected connectors, three representative joints are presented in Table 4. The collated joints differ with respect to: visibility, separability, assembly force, method of connection, need to use tools, recycling, number of connectors, number of operations necessary to assemble them and $\operatorname{CoA}$. This comparison shows significant differences regarding the evaluation of individual features.

Data prepared for statistical analyses constituted a set consisting of 84 kinds of joints collated in rows and their features collated in 8 columns. Appropriate ranks of a given joint, i.e. values $1,0.5$ or 0 , can be found on the intersection of a row with a column.

In the first step of the performed analysis, correlations between the examined traits were characterised. Due to qualitative features, Spearman's non-parametric correlation method was applied (Spearman, 1904, 1906). The value of the calculated correlation coefficient is contained in interval and indicates how strong the correlation between variables is. If the value of this coefficient belongs to (, then it is a positive correlation, which means that a value increase of the first feature is accompanied by a value increase of the second one. In the situation when the value of the correlation derives from the ) interval (negative correlation), then a value decrease of the first feature is accompanied by a value decrease of the second one. When the correlation value equals 0 , there is no dependence (absence of dependence).

In the next step of investigation of experimental material, cluster analyses were performed. Their objective was to combine objects into clusters in such a way that the similarity of objects belonging to the same cluster was the strongest, whereas it was the weakest with objects from the remaining clusters (Everitt, 1974). This kind of analysis is employed widely in order to organise data into sensible structures or to group analysed data (Romesburg, 1984, Karimizadeh at al., 2012). Data for cluster analyses were prepared in numerical form on the basis of joint assessment values, whose examples are shown in Table 4. Ward's agglomeration method (Ward, 1963) based on the Euclidean metric was applied for the analysis. It consists in combining such objects, which ensure minimum sum of square distances from the centre of gravity of a new cluster they form. As the result of such analysis, a den- 
Podskarbi, Smardzewski, Moliński, Molińska-Glura: Design Methodology of New...

Table 3 List of joints used for statistical analysis

Tablica 3. Popis spojeva korištenih za statističku analizu

\begin{tabular}{|c|c|c|c|c|c|c|c|}
\hline $\begin{array}{l}\text { Group } \\
\text { Skupina }\end{array}$ & $\begin{array}{l}\text { Picture } \\
\text { Slika }\end{array}$ & $\begin{array}{l}\text { Name } \\
\text { Naziv }\end{array}$ & $\begin{array}{c}\text { Code } \\
\text { Kod }\end{array}$ & $\begin{array}{l}\text { Group } \\
\text { Skupina }\end{array}$ & $\begin{array}{l}\text { Picture } \\
\text { Slika }\end{array}$ & $\begin{array}{l}\text { Name } \\
\text { Naziv }\end{array}$ & $\begin{array}{c}\text { Code } \\
\text { Kod }\end{array}$ \\
\hline \multirow{9}{*}{$\begin{array}{l}\text { GLUE } \\
\text { APP }\end{array}$} & & $\begin{array}{l}\text { FURNITURE } \\
\text { DOWEL }\end{array}$ & AAA & & & $\begin{array}{l}\text { LE BELGE } \\
\text { SYSTEM }\end{array}$ & CAM \\
\hline & & $\begin{array}{l}\text { ORIGINAL } \\
\text { BISCUIT }\end{array}$ & $\mathrm{AAB}$ & \multirow{20}{*}{ WEDGE } & & CHAMP & DAA \\
\hline & & DOMINO & AAC & & & SUNNY & DAB \\
\hline & & C-20 & $\mathrm{AAD}$ & & & $\begin{array}{l}\text { EVERFIX + } \\
\text { MANDREL }\end{array}$ & DAC \\
\hline & & BISCO P-10 & $\mathrm{AAE}$ & & & METAL & DAD \\
\hline & & $\begin{array}{l}\text { PLASTIC } \\
\text { DOWEL }\end{array}$ & AAF & & & $\begin{array}{l}\text { EVERFIX + } \\
\text { DUPLO }\end{array}$ & DAE \\
\hline & & FAST(GLUE) & AAG & & & TENSO P-14 & DAF \\
\hline & & MINI CLICK & AAH & & & $\begin{array}{l}\text { QUICK SET } \\
\text { SYSTEM }\end{array}$ & DAG \\
\hline & $\rightleftharpoons$ & CLIPS & AAI & & & CLICK & DAH \\
\hline \multirow{12}{*}{ CATCH } & $=0$ & RASTEX & BAA & & & FAST & DAI \\
\hline & & $\begin{array}{l}\text { ROSTRO + } \\
\text { INSERT NUT }\end{array}$ & BAB & & & SIMPLEX & DAJ \\
\hline & & EASY CON & BAC & & & VB 160 & DAK \\
\hline & & $\begin{array}{l}\text { CLAMEX } \\
\text { P-15 }\end{array}$ & BAD & & & MODOS & DAL \\
\hline & & $\begin{array}{c}\text { BLUM } \\
\text { COUPLING }\end{array}$ & BAE & & & TEAM 7 & DAM \\
\hline & & $\begin{array}{l}\text { ZIPBOLT } \\
\text { MINI }\end{array}$ & BAF & & & CHICO & DAN \\
\hline & & $\begin{array}{l}\text { K-D } 512+ \\
\text { INSERT NUT }\end{array}$ & BAG & & 46) & DUO 35 & DAO \\
\hline & & STABILOFIX & BAH & & $\mathbb{N}_{<\infty}$ & UNO 30 & DAP \\
\hline & & $\begin{array}{l}\text { ZIPBOLT } \\
\text { NEW }\end{array}$ & BAI & & & M. S. + PIN & DAQ \\
\hline & & $\begin{array}{l}\text { SOLO } 32+ \\
\text { SCREW }\end{array}$ & BAJ & & $\begin{array}{l}\alpha=0 \\
d=0\end{array}$ & $\begin{array}{l}\text { M. S. ANTI } \\
\text { TORSION }\end{array}$ & DAR \\
\hline & & VB 90-180 T & BAK & & & $\begin{array}{l}\text { DUO- } \\
\text { SYSTEM }\end{array}$ & DAS \\
\hline & & VB $45-90 \mathrm{~T}$ & BAL & & & SCLICK & DAT \\
\hline
\end{tabular}


....... Podskarbi, Smardzewski, Moliński, Molińska-Glura: Design Methodology of New...

Table 3 Continuation

Tablica 3. Nastavak tablice

\begin{tabular}{|c|c|c|c|}
\hline & & VB $25 \mathrm{~T}$ & BAM \\
\hline & & ELEFANT & BAN \\
\hline & $F=14$ & ELICA & $\mathrm{BAO}$ \\
\hline & & $\begin{array}{c}\text { MANDREL } \\
\text { M6 + SLEEVE }\end{array}$ & BAP \\
\hline & & SLIMFIX & BAQ \\
\hline & 20 & $\begin{array}{c}\text { OFON } \\
\text { SYSTEM }\end{array}$ & BAR \\
\hline & & $\begin{array}{l}\text { ZIPBOLT } \\
\text { FAST FIT }\end{array}$ & BAS \\
\hline & & $\begin{array}{c}\text { ROBO + } \\
\text { INSERT NUT }\end{array}$ & BAT \\
\hline & & TOFIX RTA & $\mathrm{BAU}$ \\
\hline \multirow{12}{*}{$\begin{array}{c}\text { SCREW } \\
\text { AND } \\
\text { BOLT }\end{array}$} & & PUSHFIX & CAA \\
\hline & & VB 16 & $\mathrm{CAB}$ \\
\hline & & TZ 321 & $\mathrm{CAC}$ \\
\hline & & CORNERFIX & CAD \\
\hline & & VALKOMP & CAE \\
\hline & & VHS 32 & CAF \\
\hline & ? & CONFIRMAT & $\mathrm{CAG}$ \\
\hline & & RV & $\mathrm{CAH}$ \\
\hline & & PLY 90 & CAI \\
\hline & & CROSS & $\mathrm{CAJ}$ \\
\hline & & $\begin{array}{l}\text { MIEKE } \\
\text { MAIJER }\end{array}$ & CAK \\
\hline & & A-JOINTS & CAL \\
\hline
\end{tabular}

\begin{tabular}{|c|c|c|c|}
\hline & ब. & $\begin{array}{c}\text { RAFIX TAB } \\
20\end{array}$ & DAU \\
\hline & 0 & RAFIX 30 & DAW \\
\hline & & $\begin{array}{c}\text { TOOLEX VB } \\
54\end{array}$ & DAX \\
\hline & & CLICK PRO & DAY \\
\hline & & MULTI-CLIP & DAZ \\
\hline & & BALL & DBA \\
\hline & & NOMADIC & DBB \\
\hline & & $\begin{array}{l}\text { WHY THE } \\
\text { FRIDAY }\end{array}$ & DBC \\
\hline & & $\begin{array}{l}\text { DOWEL } \\
\text { PLASTIC }\end{array}$ & DBD \\
\hline & 4 & $\begin{array}{c}\text { DOUBLE } \\
\text { DOVETAIL } \\
\text { M/D }\end{array}$ & DBE \\
\hline & & $\begin{array}{l}\text { MILLER } \\
\text { DOWEL } \\
\text { SYSTEM } \\
\end{array}$ & DBF \\
\hline & & JOIN NAILS & DBG \\
\hline & & E-20 & DBH \\
\hline & & $\begin{array}{c}\text { HOFFMAN } \\
\text { SYSTEM }\end{array}$ & DBI \\
\hline & & $\begin{array}{c}\text { CHAIR } \\
\text { COUPLING }\end{array}$ & DBJ \\
\hline & & $\begin{array}{c}\text { TUCK } \\
\text { SYSTEM }\end{array}$ & DBK \\
\hline & & $\begin{array}{c}\text { TOFIX RTA + } \\
\text { MANDREL }\end{array}$ & DBL \\
\hline \multirow{3}{*}{ SPRING } & & 63 DEGREES & EAA \\
\hline & & STICK LETS & EAB \\
\hline & y & $\begin{array}{l}\text { SPRING- } \\
\text { BOLT } \\
\text { SYSTEM }\end{array}$ & EAC \\
\hline MAGNET & 34 & INVIS & FAA \\
\hline
\end{tabular}


Table 4 Examples of furniture joints evaluation

Tablica 4. Primjeri vrednovanja spojeva za namještaj

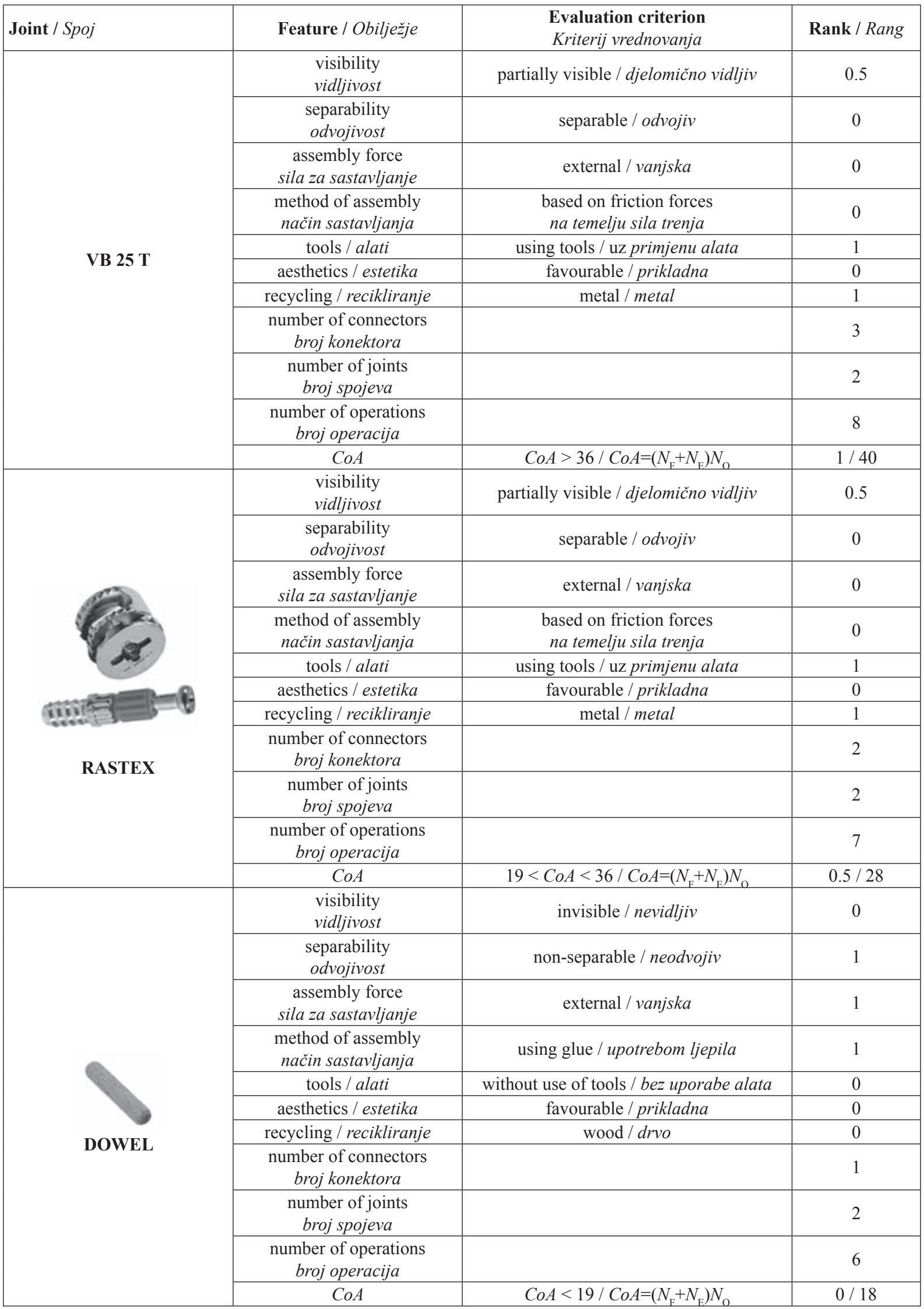

drogram is obtained, which presents a graphic interpretation of the obtained clusters.

Cluster analyses were performed for individual eight features as well as for 84 considered joints. On the basis of the obtained results, it will be possible to select joints and features, which constitute fundamental design assumptions for joint construction of skeleton furniture. 


\section{RESULTS}

\section{REZULTATI}

First, the authors analysed features and then joints. Table 5 presents values of Spearman's correlation coefficients, which provide non-parametrical measure of statistical dependences between two variables.

In the case of the examined group of features, the value of Spearman's correlation coefficients in the second column confirms a significant $(*)$ statistical dependence between "aesthetics" and "visibility" features. This correlation amounts to $0.47^{*}$, which means that the statistical dependence between these features is proportional. Therefore, if the probability of occurrence of aesthetic joints increases for "aesthetics", then for "visibility" - the probability of occurrence of externally invisible joints also increases. On the other hand, the value of the correlation coefficient between "assembly force" and "visibility" is significant and negative $(0.52 *)$, which indicates that the statistical correlation between them is inversely proportional. If for "assembly force" the probability of occurrence of joints with internal assembly force decreases, then for "visibility", the probability of occurrence of externally invisible joints increases. The correlation between "CoA" and "separability" amounts to $-0.46^{*}$, therefore the statistical dependence is significant and inversely proportional. If for " $\mathrm{CoA}$ " the probability of occurrence of joints with easy assembly decreases, then the probability of occurrence of separable joints increases for "separability". The value of correlation coefficient between "CoA" and "tools" is 0.45 , where statistical dependence is significant and proportional. If the probability of occurrence of joints with easy assembly increases for "CoA", then for "separability", the probability of occurrence of joints which do not require the use of tools increases. The highest value of the correlation coefficient in Table 5 occurs between "recycling" and "tools" $\left(0.56^{*}\right)$. This means that if the probability of occurrence of wooden connecting links decreases for "recycling", then for "tools" - the probability of occurrence of joints, which do not require the application of tools, declines. Table 5 shows the value of the correlation coefficient between individual features ranging between -0.58 and 0.56 .

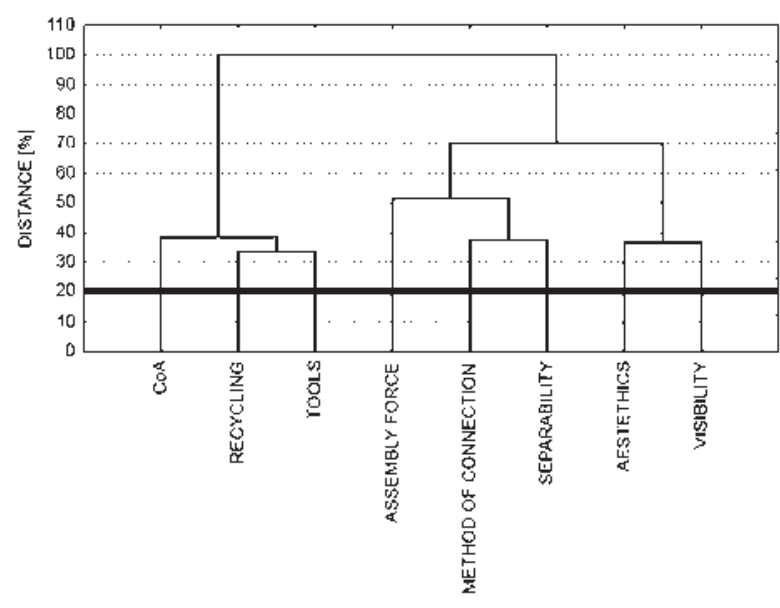

Figure 1 Cluster analysis for features

Slika 1. Klasterska analiza obilježja konstrukcijskih spojeva

Next, cluster analysis aggregating individual features and joints was carried out. Fig. 1 presents clusters for the analysed features.

Figure 1 clearly shows that "recycling" and "tools" features form a cluster, which is characterised by the shortest agglomeration distance $(34 \%)$. This is also confirmed by the value of the correlation coefficient $\left(0.56^{*}\right)$ (Table 5). The remaining features such as: "CoA", "assembly force" - "method of connection" "separability" and "aesthetics" - "visibility" exhibit similar binding distances - from $36 \%$ to $52 \%$. Statistical dependences between these features are also corroborated by the results of correlation calculations found in Table 5, ranging from 0.3 to 0.5. Differences and similarities between agglomerations found in individual clusters are so conspicuous that it is difficult to indicate unequivocally where the expected boundary of aggregation distances should occur. Nevertheless, adopting the assumption that variability between elements inside individual clusters should not exceed 20 $\%$, the dendrogram arms were cut off at this value and this yielded eight autonomic sets. The "CoA" feature does not specify the ease of assembly of a given joint and the number of connectors. The "recycling" feature fails to indicate the type of appropriate material, while the "tools" feature does not specify whether tools should be employed during the assembly process. The

Table 5 Values of Spearman's correlation coefficients

Tablica 5. Vrijednosti Spearmanova koeficijenta korelacije

\begin{tabular}{|l|c|c|c|c|c|c|c|c|}
\hline $\begin{array}{l}\text { Variable } \\
\text { Varijabla }\end{array}$ & $\begin{array}{l}\text { Visibility } \\
\text { Vidljivost }\end{array}$ & $\begin{array}{c}\text { Separability } \\
\text { Odvojivost }\end{array}$ & $\begin{array}{c}\text { Assembly } \\
\text { force } \\
\text { Sila za } \\
\text { sastavljanje }\end{array}$ & $\begin{array}{c}\text { Method of } \\
\text { assembly } \\
\text { Način } \\
\text { sastavljanja }\end{array}$ & $\begin{array}{c}\text { Tools } \\
\text { Alati }\end{array}$ & $\begin{array}{c}\text { Aesthetics } \\
\text { Estetika }\end{array}$ & $\begin{array}{c}\text { Recycling } \\
\text { Recikliranje }\end{array}$ \\
\hline Visibility / Vidljivost & 1.00 & & & & & & & \\
\hline Separability / Odvojivost & $-0.50^{*}$ & 1.00 & & & & & & \\
\hline $\begin{array}{l}\text { Assembly force } \\
\text { Sila za sastavljanje }\end{array}$ & $-0.52^{*}$ & $0.54^{*}$ & 1.00 & & & & & \\
\hline $\begin{array}{l}\text { Method of assembly } \\
\text { Način sastavljanja }\end{array}$ & $-0.27^{*}$ & $0.35^{*}$ & $0.29^{*}$ & 1.00 & & & & \\
\hline Tools / Alati & $0.07^{*}$ & $-0.28^{*}$ & $-0.33^{*}$ & $-0.48^{*}$ & 1.00 & & & \\
\hline Aesthetics / Estetika & $0.47^{*}$ & $-0.09^{*}$ & -0.12 & -0.05 & 0.19 & 1.00 & & \\
\hline Recycling / Recikliranje & $0.30^{*}$ & $-0.51^{*}$ & $-0.39^{*}$ & $-0.58^{*}$ & $0.56^{*}$ & 0.08 & 1.00 & \\
\hline CoA & 0.13 & $-0.46^{*}$ & -0.18 & $-0.34^{*}$ & $0.45^{*}$ & 0.01 & $0.49^{*}$ & 1.00 \\
\hline
\end{tabular}




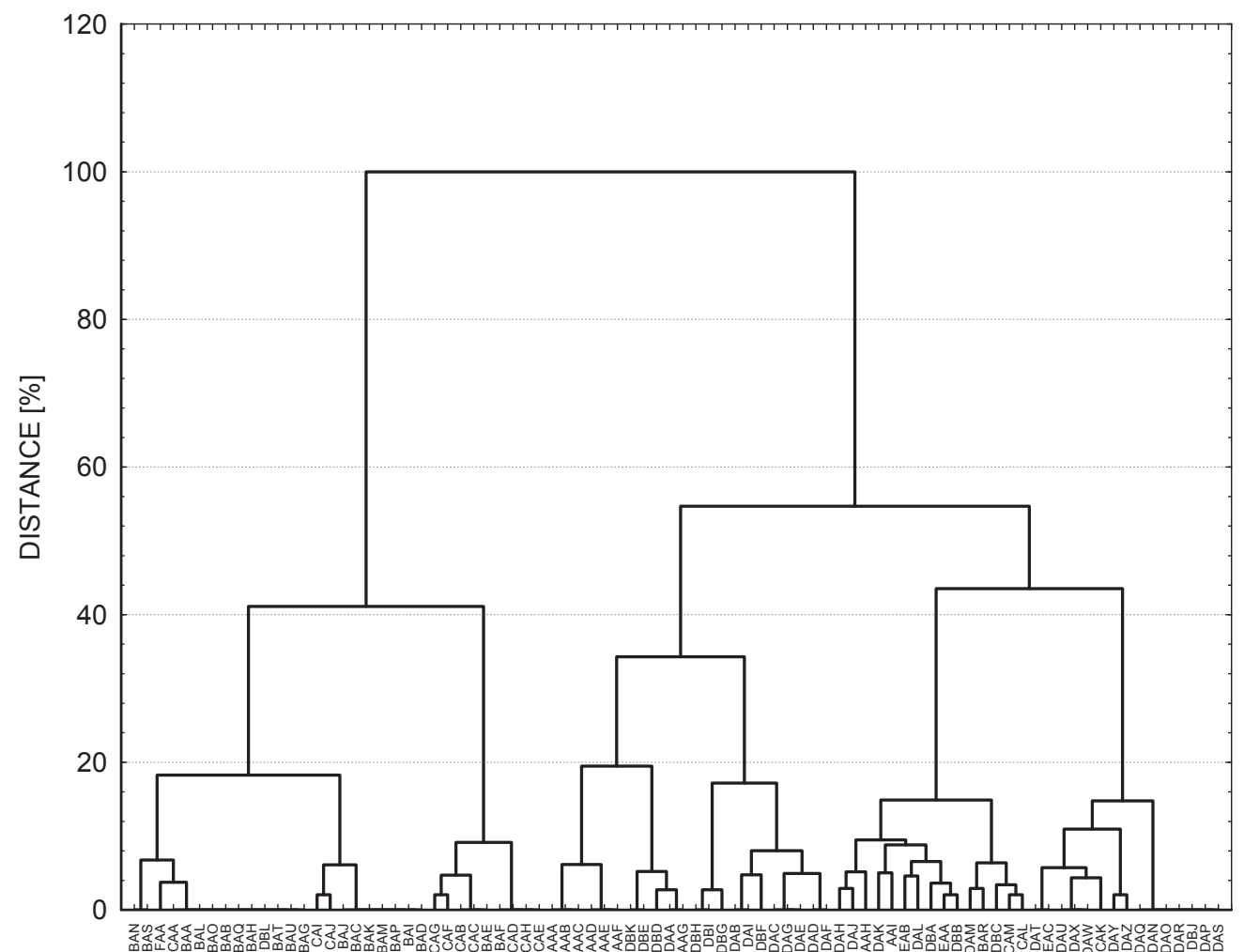

Figure 2 Cluster analysis tor joints

Slika 2. Klasterska analiza spojeva

"separability" feature does not indicate whether a permanent or dismountable joint would be desirable. The feature "method of connection" fails to indicate whether glue should be used in the joint or if it should employ the principle of friction forces. The feature "assembly force" does not specify what force should be used. The "aesthetic" feature does not say anything about its importance and the trait "visibility" fails to indicate the degree of visibility.

Both Spearman's correlation analysis of features and cluster analysis emphasise the necessity to take all features into consideration in further design assumptions.

Fig. 2 presents clusters of joints characterised by similar properties. By cutting off dendrogram arms at the boundary of $20 \%$, six autonomous subsets were obtained. This indicates that element variability inside individual subsets cannot exceed $20 \%$.

The first cluster comprises the following 23 joints: BAN, BAS, CAA, BAA, BAL, BAO, BAT, BAU, BAG, BAB, BAQ, BAH, DBL, FAA, BAJ, BAC, BAK, BAM, BAP, BAI, BAD, CAI, CAJ and $\mathrm{BAC}$. These are dismountable joints using internal assembly forces associated with the construction of wedges causing friction between connectors. They require the application of additional tools for assembly. They also exert a favourable effect on aesthetics of joints. They vary among one another with respect to: visibility and CoA ranging from 15 to 112 .

The second cluster consists of nine joints: $\mathrm{CAB}$, CAC, BAE, CAG, CAF, BAF, CAD, CAH and CAE. They comprise separable joints, which - similarly to those mentioned above - use internal friction forces and require the application of additional tools for their assembly. They have an unfavourable influence on joint aesthetics. They vary among one another with respect to: visibility and CoA ranging from 12 to 108 .

The third cluster is made up of eleven joints: AAA, AAB, AAC, AAD, AAE, AAF, DBK, DBD, DBE, DAA and AAG. These are joints with externally invisible and non-separable connections, which require additional outside force in the assembly process. However, these connectors do not require the use of additional tools during the process of assembly and have an advantageous effect on joints aesthetics. They vary among one another with respect to: the method of assembly, recycling and $C o A$ ranging from 12 to 28 .

The fourth cluster comprises eleven joints: DAB, DAI, DBF, DAC, DAG, DAE, DAD, DAF, DBH, DBI and DBG. All of them are non-separable and the buyer must apply an additional external force to assemble them. These joints use internal friction forces and require the use of additional tools during the process of assembly. Within the group, they differ among one another with respect to: visibility, aesthetics, recycling and $C o A$ ranging from 12 to 104 .

The fifth cluster consists of fifteen joints: DAH, DAJ, AAH, DAK, EAB, DAL, AAI, EAA, DBB, DBA, DAM, BAR, DBC, CAM, CAL and they require from the user the application of additional tools in the course of assembly. They differ among one another with regard to: visibility, separability, assembly force, method of connection, aesthetics, recycling and $\operatorname{CoA}$ ranging from 6 to 49 .

The sixth cluster includes fifteen joints: DAT, EAC, DAU, DAX, DAW, CAK, DAY, DAZ, DAQ, DAN, DAO, DAR, DBJ, DAP, DAS. These are dismountable joints, which require additional external 


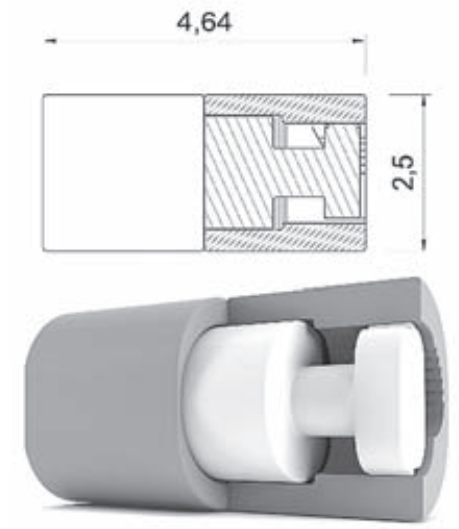

a)

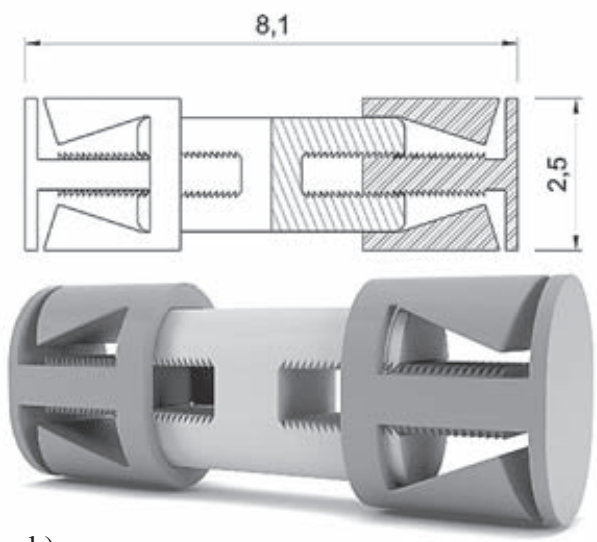

b)

Figure 3 Examples of new joints corresponding to: a) agglomeration one, b) agglomeration three Slika 3. Primjeri novih spojeva koji odgovaraju: a) aglomeraciji jedan, b) aglomeraciji tri

force in the course of assembly. They use internal friction forces and need additional tools. They differ with respect to: visibility, aesthetics and $C O A$ ranging from 20 to 320 .

From among the above-mentioned six groups of clusters, the first and third groups appear most advantageous from the point of view of their functionality and construction. The first set is advantageous because it comprises dismountable joints of complex constructions using internal assembly forces, which exert a favourable influence on joint aesthetics. Such joints can be employed in furniture constructions intended for individual assembly and are characterised by good mechanical properties, in particular long-term use. The third set contains connectors and connecting links ensuring easy furniture assembly with no necessity to apply additional tools. These joints are characterised by simple construction, they are non-separable and nonvisible, which contributes to their attractive appearance. In addition, they are characterised by considerable strength and durable utilisation.

On the basis of the performed experiments and analyses, detailed recommendations for designing joints for skeleton furniture were elaborated. A new joint should be characterised by:

- lack of visibility,

- separability,

- necessity to employ additional external force in the course of assembly,

- method of assembly based on the action of internal friction forces,

- no necessity for the user to apply additional tools during the assembly process,

- favourable appearance,

- easy for recycling,

- CoA, not exceeding 36.

\section{CONCLUSIONS}

\section{ZAKLJUČAK}

On the basis of the performed statistical analyses, a number of assumptions were developed to be used when designing a new joint for skeleton furniture.
First, the applied joints were divided into groups in accordance with widely applied engineering practice (Table 3). Statistical correctness of the elaborated classifications was corroborated following careful examination of Spearman's correlation coefficient values and cluster analysis using Ward's method. The performed cluster analyses (Fig. 1) and values of Spearman's correlation coefficients failed to provide a basis allowing identification of a trait to be used as a constituent of design assumptions. In the cluster analysis (Fig. 2), the authors identified sets of joints which, although differing among one another, were intrinsically consistent and which characterised individual features. On this basis, unequivocal design assumptions were developed. Values of features in the obtained clusters were frequently repeated and they included, among others: separability, need of an additional force during the assembly process, utilisation of internal friction forces as well as the necessity to employ additional tools during assembly. Traits referring to: external visibility and aesthetics occurred in the clusters most rarely. The developed method made it possible to elaborate an objective classification of the examined joints with respect to their functionality and construction. Properties of joints agglomerated in cluster one and three turned out to be most advantageous. They were found to contain the best premises, which can be used to elaborate design assumptions of a new joint. Examples of new joint constructions corresponding to the developed assumptions are presented in Fig. 3.

According to Table 1, the new joints are characterised by: lack of visibility, separability, necessity to employ additional external force in the course of assembly, method of assembly based on the action of internal friction forces, no necessity for the user to apply additional tools during the assembly process, favourable appearance, easy for recycling, $C O A$ equal to 25 .

\section{REFERENCES}

5. LITERATURA

1. Akcay, H.; Eckelman, C. A.; Haviarova, E., 2005: Withdrawal, shear, and bending moment capacities of round 
mortise and tenon timber framing joints. Forest Products Journal, 55 (6): 60-72.

2. Altinok, M.; Taş, H. H.; Sancak, E., 2009: Load carrying capacity of spline joints as affected by board and adhesives type. Scientific Research and Essays, 4 (5): 479-483.

3. Atar, M.; Özçifçi, A., 2008: The effect of screw and back panels on the strength of corner joints in case furniture. Materials and Design, 29 (2): 519-525. http://dx.doi.org/10.1016/j.matdes.2007.01.015.

4. Buzan, B.; Buzan, T., 2004: Mapy twoich myśli. Łódź, Wydawnictwo RAVI.

5. Daly, S. R.; Yilmaz, S.; Christian, J. L.; Seifert, C. M.; Gonzalez, R., 2012: Design heuristic in engineering concept generation. Journal of Engineering Education, 101 (4): 601-629.

http://dx.doi.org/10.1002/j.2168-9830.2012.tb01121.x.

6. Dzięgielewski, S.; Zenkteler, M., 1975: Badania nad połączeniami szkieletowych konstrukcji mebli z drewna. Folia Forestalia Polonica, Seria B, Zeszyt 12: 133-156.

7. Eckelman, C. A., 1997: Bending strength of corner joints constructed with injection-molded splines. Forest Products Journal, 47 (4): 89-92.

8. Eckelman, C. A., 2003: Textbook of Product Engineering and Strength Design of Furniture. West Lafayette, Indiana, Purdue University Press, pp. 619-699.

9. Eckelman, C. A.; Haviarova, E., 2008: Rectangular mortise and tenon semirigid joint connection factors. Forest Products Journal, 58 (12): 49-55.

10. Everitt, B., 1974: Cluster analysis. London, Heinemann Educational Books Ltd.

11. Ginalski, J.; Liskiewicz, M.; Seweryn, J., 1994: Rozwój nowego produktu. Kraków, Wydawnictwo Akademii Sztuk Pięknych w Krakowie - Wydział Form Przemysłowych.

12. Karimizadeh, R.; Mohammadi, M.; Sabaghnia, N.; Shefazadeh, M. K., 2012: Using Huehn's Nonparametric stability statistics to investigate genotype $\times$ environment interaction. Notulae Botanicae Horti Agrobotanici Cluj-Napoca, 40 (1): 293-301.

13. Kociszewski, M., 2005: Stiffness and load capacity of biscuit corner joints. Folia Forestalia Polonica, Seria B, Zeszyt, 36: 39-47.

14. Liu, W. Q.; Eckelman, C. A., 1998: Effect of number of fasteners on the strength of corner joints for cases. Forest Products Journal, 48 (1): 93-95.

15. Maleki, S.; Derikvand, M.; Dalvand, M.; Ebrahimi, G., 2012: Load-carrying capacity of mitered furniture corner joints with dovetail keys under diagonal tension load. Turkish Journal of Agriculture and Forestry, 36 (5): 636643. http://dx.doi.org/10.3906/tar-1112-44.

16. Romesburg, H., 1984: Cluster analysis for researchers. Belmont, California, Lifetime Learning Publications.

17. Smardzewski, J.; Prekrat, S., 2002: Stress distribution in disconnected furniture joints. Electronic Journal of Polish Agricultural University, Wood Technology, 5 (2): 1-7.

18. Smardzewski, J.; Papuga, T., 2004: Stress Distribution in angle joints of skeleton furniture. Electronic Journal of Polish Agricultural Universities, Wood Technology, 7 (1).
19. Smardzewski, J., 2008: Effect of wood species and glue type on contact stresses in a mortise and tenon joint. Journal of Mechanical Engineering Science, 222 (12): 2293-2299.

http://dx.doi.org/10.1243/09544062JMES1084.

20. Smardzewski, J., 2015: Furniture design: Stiffness and Strength Analysis of Skeletal Furniture. Springer International Publishing, pp. 319-455. http://dx.doi.org/10.1007/978-3-319-19533-9_6.

21. Smardzewski, J., 2015a: Złącze stożkowe i połączenie kątowe, zwłaszcza do mebli skrzyniowych. Zgłoszenie patentowe w UP RP, numer P.412167, Polska.

22. Spearman, C., 1904: The proof and measurement of association between two things. The American Journal of Psychology, 15 (1): 72-101.

http://dx.doi.org/10.2307/1412159.

23. Spearman, C., 1906: Footrule for measuring correlation. British Journal of Psychology, 2: 89-108. http://dx.doi.org/10.1111/j.2044-8295.1906.tb00174.x.

24. Tankut, N., 2009: Effect of Various Factors on the Rigidity of Furniture Cases. African Journal of Biotechnology, 8 (20): 5265-5270.

25. Tankut, A. N.; Tankut N., 2009: Investigations the effects of fastener, glue, and composite material types on the strength of corner joints in case-type furniture construction. Material and Design, 30 (10): 4175-4182. http://dx.doi.org/10.1016/j.matdes.2009.04.038.

26. Vajna, S.; Kittel, K., 2009: An Approach to Compare Product Development Methods. In: Proceedings of the 17th International Conference on Engineering Design (ICED 09). Palo Alto, California: Design Methods and Tools, 5: 313-324.

27. Vassiliou, V.; Barboutis, I., 2009: Bending strength of furniture corner joint constructed with insert fittings. Forestry and Wood Products Technology, 67: 268-274.

28. Ward, J. H., 1963: Hierarchical grouping to optimize an objective function. Journal of the American Statistical Association, 58 (301): 236-244. http://dx.doi.org/10.1080/01621459.1963.10500845.

29. Yerlikaya, N. C.; Aktas, A., 2012: Enhancement of loadcarrying capacity of corner joints in case-type furniture. Materials and Design, 37 (5): 393-401. http://dx.doi.org/10.1016/j.matdes.2012.01.010.

\section{Corresponding address:}

\section{MARCIN PODSKARBI, PhD student}

Faculty of Wood Technology

Department of Furniture Design

Wojska Polskiego 38/42

60-637 Poznan, POLAND

e-mail: marcin.podskarbi@up.poznan.pl 